\title{
EVALUATION OF LIGHT SHELF DESIGN PERFORMANCES TO THE DAYLIGHT'S SUNLIGHT PENETRATION ON SINAR MAS LAND PLAZA BUILDING TANGERANG TO INCREASE THE GREEN MARK ASSESSMENT
}

\author{
${ }^{1}$ Monica Elizabeth. ${ }^{2}$ Ryani Gunawan, S.T, M.T. \\ 1 Student in the Bachelor's (S-1) Study Program in Architecture \\ at Parahyangan Catholic University \\ ${ }^{2}$ Senior lecturer in the Bachelor's (S-1) Study Program in Architecture \\ at Parahyangan Catholic University
}

\begin{abstract}
Light shelf is one of the daylighting strategies used in Sinar Mas Land Plaza Tangerang. However, based on observations made on the object of research, light shelf design on Sinar Mas Land Plaza Tangerang is not optimal. This is because the purpose of a light shelf that should reflect sunlight directly to enter much deeper into the room does not occur. This is evident in the use of artificial lighting in areas close to openings, so it is necessary to evaluate the light shelf design to improve light shelf performance, which is also useful for improving the Green Mark BCA assessment.

This research uses experimental research method to see daylight penetration by simulating model using Ecotect which can simulate model by ray simulation. Evaluation is done by manipulating variables from light shelf design such as ceiling design aspect, light shelf shape, and light shelf slope to see effective light shelf design to be applied to Sinar Mas Land Plaza Tangerang. Based on the research, it can be concluded that the performance of the existing light shelf design is not optimal because of the fins that are above the light shelf to block out direct sunlight. The sloped ceiling design also affects the daylight penetration distance into space. Light shelf design that effective at North orientation is a light shelf design with curved shapes, while the light shelf design that effective at South orientation is a light shelf design with a slope of $20^{\circ}$. Improving the light shelf design can increase the Green Mark rating up to 8 points.
\end{abstract}

Key Words: light shelf, daylight penetration, assessment of Green Mark, Ecotect

\section{EVALUASI KINERJA DESAIN LIGHT SHELF TERHADAP PENETRASI CAHAYA ALAMI SIANG HARI PADA BANGUNAN SINAR MAS LAND PLAZA TANGERANG UNTUK MENINGKATKAN PENILAIAN GREEN MARK}

\author{
${ }^{1}$ Monica Elizabeth. ${ }^{2}$ Ryani Gunawan, S.T, M.T. \\ ${ }^{1}$ Mahasiswa S1 Program Studi Arsitektur Universitas Katolik Parahyangan. \\ ${ }^{2}$ Dosen Pembimbing S1 Program Studi Arsitektur Universitas Katolik Parahyangan
}

\begin{abstract}
Abstrak- Light shelf merupakan salah satu strategi pencahayaan alami siang hari yang digunakan pada bangunan Sinar Mas Land Plaza Tangerang.Namun berdasarkan pengamatan yang dilakukan pada objek penelitian, desain light shelf pada bangunan Sinar Mas Land Plaza Tangerang belum optimal. Hal ini dikarenakantujuan dari light shelf yang seharusnya memantulkan cahaya matahari langsung untuk masuk jauh lebih dalam ke dalam ruangan tidak terjadi. Hal tersebut terlihat dengan masih digunakannya pencahayaan buatan pada area yang dekat dengan bukaan, sehingga perlu evaluasi desain light shelf untuk meningkatkan kinerja light shelf, yang berguna juga untuk meningkatkan penilaian Green Mark BCA.

Penelitian ini menggunakan metode penelitian eksperimental untuk melihat penetrasi cahaya alami siang hari dengan mensimulasikan model menggunakan Ecotect yang mana dapat mensimulasikan model dengan cararay simulation. Evaluasi yang dilakukan adalah dengan merekayasa variabel dari desain light shelfseperti
\end{abstract}

\footnotetext{
${ }^{1}$ Corresponding Author: monica.oncezt21@gmail.com
} 
aspek desain plafon, bentuk light shelf, serta kemiringan light shelf untuk melihat desain light shelf yang efektif untuk diterapkan pada bangunan Sinar Mas Land Plaza.Berdasarkan penelitian yang dilakukan, dapat disimpulkan bahwa kinerja desain light shelf eksisting belum optimal karenaadanya sirip yang berada di atas light shelf sehingga menghalangi cahaya matahari langsung. Desain plafon miring juga mempengaruhi jarak penetrasi cahaya alami siang hari ke dalam ruang. Desain light shelf pada orientasi Utara yang efektif adalah desain light shelf dengan bentuk lengkung, sedangkan desain light shelf pada orientasi Selatan yang efektif adalah desain light shelfdengan kemiringan $20^{\circ}$. Upaya perbaikan desain light shelf dapat meningkatkan penilaian Green Mark sampai 8 poin.

Kata Kunci: light shelf, penilaian Green Mark, penetrasi cahaya alami siang hari, Ecotect

\section{PENDAHULUAN}

\subsection{LATAR BELAKANG}

Fenomena krisis energi yang tidak terbarukan dan pemanasan global telah menyadarkan para arsitek agar lebih bijak dalam menata lingkungan binaan dan menggunakan energi-energi yang terbarukan yang tersedia di alam. Menjadi tantangan tersendiri bagi arsitek untuk dapat mendesain bangunan yang menyesuaikan dengan keadaan iklim terutama di Indonesia. Salah satu caranya adalah pemanfaatan pencahayaan alami siang hari. Untuk dapat memanfaatkan secara optimal pencahayaan alami siang hari diperlukan strategi-strategi desain pada suatu bangunan.

Bangunan Sinar Mas Land Plaza memiliki desain light shelf yang mana light shelf adalah salah satu strategi desain pencahayaan alami untuk memasukkan cahaya matahari, karena light shelf memantulkan cahaya matahari langsung dari luar ke plafon yang berada di dalam ruangan kemudian hasil pantulan cahaya tersebut masuk lebih dalam ke dalam ruangan. Dalam salah satu poin di dalam rating tool Green Mark tersebut memberikan poin untuk penilaian dari subkriteria pencahayaan alami siang hari serta penilaian dari sub-kriteria fitur yang digunakan dalam desain untuk efisiensi energi dimana desain light shelf ini masuk ke dalam poin penting dalam kedua penilaian dalam sub-kriteria tersebut.

Berdasarkan teori light shelf, dengan menggunakan sistem light shelf pada bukaan samping, dapat meningkatkan penetrasi cahaya alami siang hari ke dalam bangunan, sehingga pada area yang dekat dengan bukaan samping tidak memerlukanpencahayaan buatan. Namun berdasarkan pengamatan yang dilakukan pada objek penelitian, pada area yang dekat dengan bukaan samping masih menggunakan pencahayaan buatan.
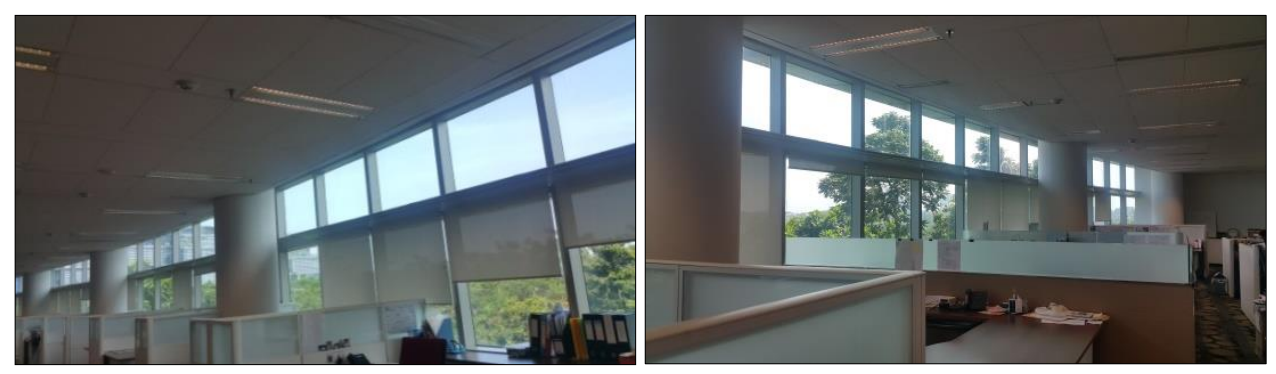

Figur 1. Keadaan dalam ruang kantor Sinar Mas Land Plaza pada siang hari.

Selain itu, desain light shelf pada bangunan Sinar Mas Land Plaza ini mempunyai desain yang sama pada orientasi bukaan Utara maupun Selatan. Dengan adanya pergerakan matahari yang berbeda setiap harinya setiap bulan serta berbagai pengaruh dari setiap elemen desain light shelf itu sendiri akan berpengaruh terhadap pemantulan cahaya matahari hingga masuk ke dalam ruangan. Mulai dari bentuk, ukuran, kemiringan light shelf itu sendiri, bentuk plafon, proporsi ruang, hingga pada material yang digunakan pada setiap elemen desain light shelfakan 
berpengaruh kepada perilaku masuknya cahaya ke dalam ruangan pada orientasi bangunan yang berbeda.

\subsection{RUMUSAN MASALAH}

(1) Peran penggunaan light shelf dalam penilaian yang diberikan dalam rating tool $B C A$ Green mark. (2) Upaya peningkatan kinerja light shelf pada bangunan Sinar Mas Land Plaza Tangerang.

\subsection{PERTANYAAN PENELITIAN}

(1) Apa peran penggunaan light shelf pada bangunan Sinar Mas Land Plaza terhadap penilaian yang diberikan dalam rating tool Green Mark BCA (Building Construction Authority)? (2) Bagaimana upaya perbaikandesain light shelf pada bangunan Sinar Mas Land Plaza dalam meningkatkan penetrasi cahaya alami siang hari ke dalam ruangan kantor jika dinilai dari bentuk light shelf, kemiringanlight shelf, dan desain plafon?

\subsection{TUJUAN PENELITIAN}

Penelitian ini dilakukan untuk mengetahui sejauh mana peran light shelf eksisting dalam penilaian Green Mark BCA dan untuk melihat kinerja light shelf eksisting. Penelitian ini dilakukan karena melihat fenomena yang terjadi pada objek penelitian bahwa kinerja light shelf belum optimal. Hal ini dikarenakan tujuan dari light shelf yang seharusnya memantulkan cahaya matahari langsung untuk masuk jauh lebih dalam ke dalam ruang kantor tidak terjadi.

Penelitian ini pun dilakukan untuk memberikan saran atau masukan dari aspek desain light shelf dalam meningkatkan penetrasi cahaya alami siang hari berdasarkan parameter desain light shelf. Saran atau masukan ini dapat berguna dalam meningkatkan penilaian atau poin yang akan didapatkan untuk meningkatkan sertifikasi Green Mark BCA.

\subsection{MANFAAT PENELITIAN}

Penelitian ini diharapkan dapat memberikan saran atau masukan dalam aspek desain di masa yang akan datang. Saran ini dapat digunakan untuk penilaian yang didapatkan oleh pihak pengembang dalam penilaian sertifikasi Green Mark BCA. Serta penelitian ini diharapkan dapat memberikan wawasan tentang desain light shelf yang tepat digunakan dalam suatu desain bangunan terutama bangunan kantor di Indonesia terutama di daerah kota Jakarta dan Tangerang, dengan berdasarkan pada parameter desain light shelf dan juga memperhatikan orientasi bangunan Utara-Selatan dalam mendesain karena akan berpengaruh terhadap perilaku atau penetrasi cahaya alami siang hari ke dalam suatu ruangan.

\section{PERAN LIGHT SHELF DALAM PENCAHAYAAN ALAMI SIANG HARI DAN KRITERIA PENILAIAN GREEN MARK \\ 2.1. LIGHT SHELF SEBAGAI BAGIAN DARI STRATEGI PENCAHAYAAN ALAMI SIANG HARI}

Cahaya merupakan aspek yang sangat berperan dan tidak dapat dipisahkan dari desain arsitektur.Cahaya juga menjadikan lingkungan aman dan nyaman dan berkaitan erat dengan aktivitas serta produktivitas manusia.Cahaya didefinisikan sebagai bagian dari spektrum elektromagnetik yang sensitif bagi penglihatan mata manusia.

Sumber cahaya yang biasa digunakan dalam aktivitas manusia sehari-hari terdiri dari 2 yaitu pencahayaan alami dan pencahayaan buatan. Untuk cahaya matahari yang masuk ke dalam bangunan dapat dibedakan menjadi tiga (Szokolay et al, 2001), yaitu : (1) Cahaya matahari langsung. (2) Cahaya difus dari terang langit. (3) Cahaya difus dari pantulan tanah atau bangunan. 


\subsection{STRATEgI-STRATEgI PENCAHAYAAN ALAMI SIANG HARI PADA BANGUNAN}

Pencahayaan alami memiliki nilai positif seperti dapat mengurangi konsumsi energi listrik dan menghemat energi yang digunakan, bangunan dapat menjadi lebih terang karena cahaya alami itu sendiri mengandung spektrum warna yang lengkap, dan bisa menjadi nilai positif untuk fasad bangunan. Namun pencahayaan alami juga memiliki kekurangan seperti perlunya mempertimbangkan daerah pemakaian pencahayaan alami, karena apabila salah konsep akan menyebabkan panas yang berlebih pada bangunan dan membuat tidak nyaman serta bangunan menjadi terlalu terang dan panas pada siang hari, terutama pada bagian barat atau timur bangunan.

Ada beberapa faktor yang perlu diperhatikan pada pencahayaan alami seperti kapan dan berapa lama sinar tersebut masuk dan mengganggu aktivitas kerja dalam hunian, kemudian letak bangunan terhadap garis lintang bumi, serta untuk pemakaian jendela perlu dipertimbangkan jarak, letak, luas, ketinggian, dari permukaan bidang tangkap terhadap datangnya sinar.

Kualitas penerangan alami untuk suatu bangunan dapat dianggap baik apabila kuat penerangan minimal yang diperlukan selalu tercapai di semua tempat, menyeluruh pada siang hari (antara jam 08.00 hingga jam 16.00) serta distribusi cahaya merata dan tidak menimbulkan kontras yang mengganggu.

Untuk dapat mewujudkan semua prinsip-prinsip dasar dalam mendesain dengan memanfaatkan pencahayaan alami pada siang hari diperlukan strategi-strategi khusus. Strategistrategi untuk dapat mewujudkan hal tersebut (M. David Egan, 2001) yaitu: (1) Orientasi bangunan. (2) Bentuk dan letak bukaan pada bangunan. (3) Building integration. (4) Faktor ruang.

\subsection{SISTEM PENCAHAYAAN ALAMI SIANG HARI PADA BANGUNAN}

Untuk dapat menerapkan strategi-strategi pencahayaan alami siang hari dengan baik pada suatu bangunan diperlukan sistem desain pencahayaan alami siang hari yang akan digunakan pada suatu bangunan. Secara umum cahaya alami didistribusikan ke dalam ruangan melaluli bentuk dan besarnya bukaan pada suatu bangunan.Ada beberapa tipe bukaan dan desain yang digunakan dalam memasukkan pencahayaan alami ke dalam ruangan yaitu side lighting, top lighting, core lighting, dan optical lighting.

\subsection{LIGHT SHELF SEBAGAI STRATEGI PENCAHAYAAN ALAMI SIANG HARI}

Desain menggunakan pencahayaan alami adalah sebuah paduan antara seni dan ilmu pengetahuan. Tantangan terbesar dalam mendesain pencahayaan alami adalah untuk memasukkan cahaya matahari jauh ke dalam melewati ruang yang dibutuhkan tanpa membawa sifat panas dan silau dari sinar matahari tersebut. Dibutuhkan sistem yang baik untuk menangkap sinar matahari dan menyebarkannya ke dalam ruangan dengan mengontrol sifat panas dan silau agar tidak serta masuk ke dalam.Salah satu sistem tersebut adalah light shelf.

Light shelf dapat meningkatkan masuknya cahaya matahari ke dalam ruangan hanya jika menangkap dan mengalihkan sinar matahari langsung. Light shelf memiliki keuntungan yang terbatas dengan cahaya yang menyebar, ketika cuaca sedang berawan dan matahari tertutup awan. Beberapa faktor yang mempengaruhi kinerja desain light shelf yaitu: (1) Orientasi ${ }^{5}$. (2) Bentuk, ukuran, dan kemiringan ${ }^{2}$. (3) Plafon ${ }^{2}$. (4) Jendela ${ }^{2}$. (5) Shading ${ }^{2}$. (6) Bahan Material $^{2}$. (7) Maintenance.

\subsection{SUN PATH DIAGRAM}

Dalam Sun path diagram kita dapat mengetahui posisi matahari berdasarkan tanggal, bulan, dan waktu pada siang hari untuk mendapatkan besarnya sudut ketinggian matahari pada 
waktu tertentu atau yang disebut dengan altitude, dengan besaran sudut berkisar antara $0^{\circ}-90^{0}$ (Sukawi, 2010).

Sun path diagram ini digunakan untuk menentukan ketinggian matahari pada waktu siang hari dan juga menentukan posisi matahari pada bulan-bulan tertentu yaitu pada posisi terjauh dan terdekat dari objek penelitian baik pada orientasi Utara maupun Selatan. Data-data dari sun path diagram ini nantinya akan digunakan sebagai data input untuk iklim pada software Autodesk Ecotect yang digunakan untuk simulasi objek penelitian.

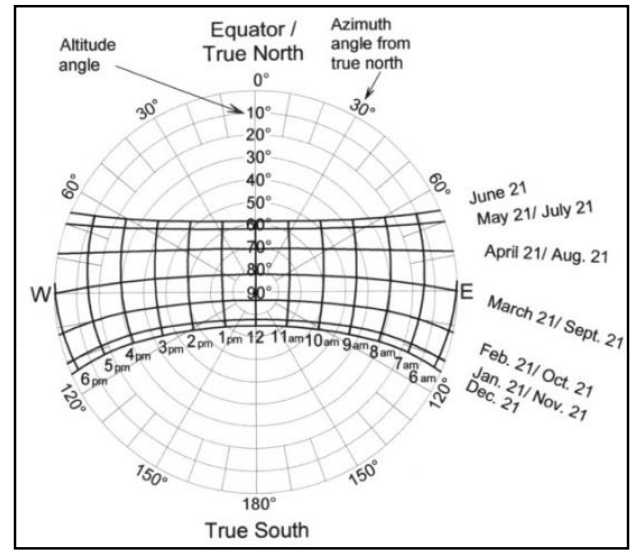

Figur 2. Sun Path Diagramkota Jakarta.

(Sumber: www.harvestingrainwater.com, diakses pada tanggal 10 April 2017)

Untuk penelitian ini dibutuhkan sampel atau variabel berupa letak atau posisi matahari pada bulan-bulan tertentu yang dominan berada di Utara dan juga Selatan. Bulan-bulan yang dipilih merupakan 2 bulan pada masing-masing orientasi Utara dan Selatan yang dimana posisi matahari berada pada sudut paling rendah dan sudut paling tinggi.

Pada orientasi Utara diambil 2 bulan yang menjadi sampel dalam penelitian ini yang dimana sudut posisi matahari paling rendah yaitu pada tanggal 21 Juni, sedangkan untuk sudut posisi matahari paling tinggi adalah pada tanggal 21 September.

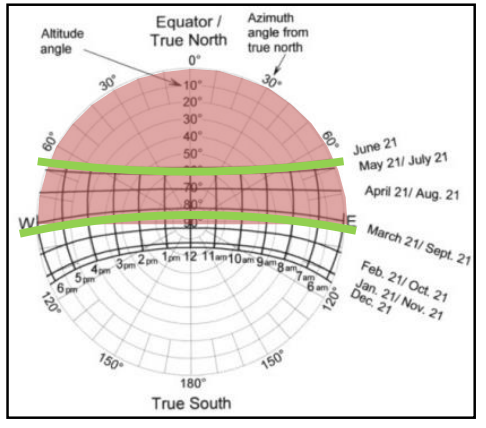

Figur 3. Sun Path Diagram kota Jakarta. (Sumber:

www.harvestingrainwater.com, diakses pada tanggal 10 April 2017) Juni.

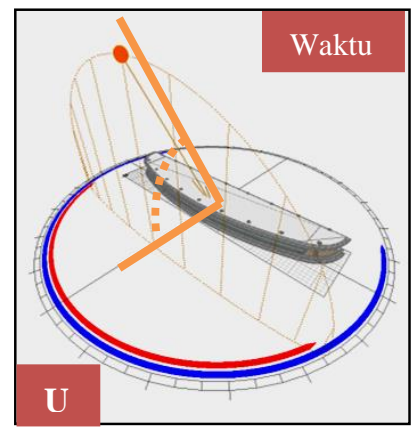

Figur 4. Sudut Posisi Matahari pada tanggal 21 Juni.

(Sumber: Autodesk Ecotect, dokumentasi sendiri, 2017)

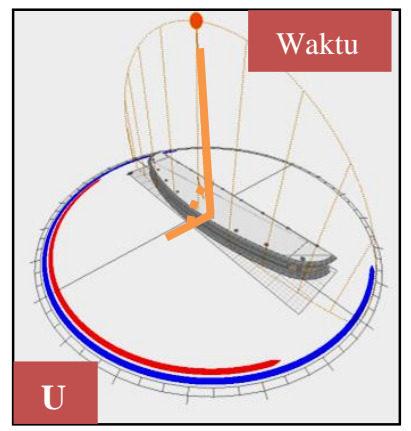

Figur 5. Sudut Posisi Matahari pada tanggal 21 September.

(Sumber: Autodesk Ecotect, dokumentasi sendiri, 2017)

Pada orientasi Selatan diambil pula 2 bulan yang menjadi sampel dalam penelitian ini yang dimana sudut posisi matahari paling rendah yaitu pada tanggal 21 Desember dan tanggal 21 Oktober untuk bulan dengan sudut posisi matahari paling tinggi. 


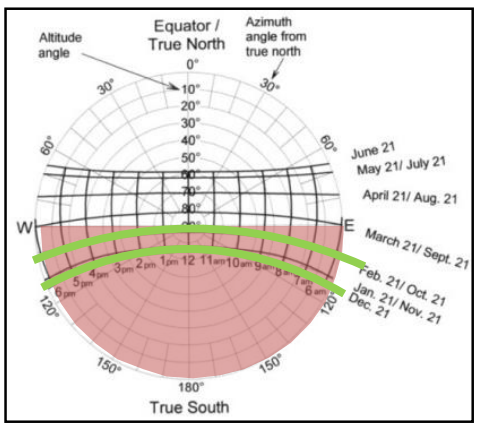

Figur 6. Sun Path Diagram kota Jakarta. (Sumber:

www.harvestingrainwater.com, diakses pada tanggal 10 April 2017)

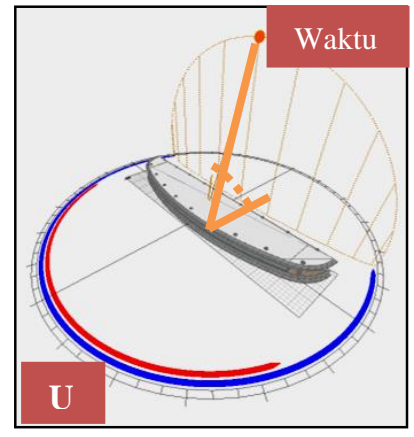

Figur 7. Sudut Posisi Matahari pada tanggal 21 Desember.

(Sumber: Autodesk Ecotect, dokumentasi sendiri, 2017)

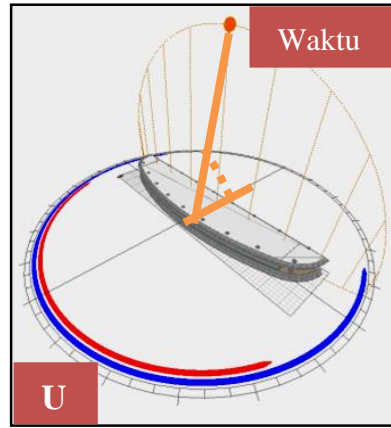

Figur 8. Sudut Posisi Matahari pada tanggal 21 Oktober.

(Sumber: Autodesk Ecotect, dokumentasi sendiri, 2017)

\subsection{AUTODESK ECOTECT}

Proses simulasi dilakukan melalui Autodesk Ecotect dengan pertimbangan software ini telah banyak dipergunakan dalam simulasi pencahayaan. Dalam Ecotect material pada bangunan dapat di definisikan secara tepat baik dengan material yang tersedia atau memasukan settingan untuk material baru. Ray simmulation, mampu mensimulasikan cahaya matahari (sunlight) yang terjadi di objek atau interior untuk melihat arah masuk dan pemantulannya.

Software Ecotect ini akan digunakan untuk mengsimulasi desain light shelf dari objek penelitian dimana sebelumnya telah ditetapkan variabel-variabel tetap dan juga variabelvariabel bebas untuk membatasi penelitian melalui simulasi tersebut. Data input yang akan dimasukkan ke dalam simulasi ini adalah data iklim sebagai penentu posisi matahari pada tanggal, bulan dan waktu yang telah ditetapkan sesuai dengan kajian teori. Kemudian data input lainnya adalah berupa desain light shelf beserta dengan jenis material yang digunakan pada desain light shelf tersebut.

Sedangkan untuk data output yang akan didapatkan adalah hasil gambar potongan yang menunjukkan hasil pemantulan cahaya alami melalui desain light shelf yang dimana cahaya alami tersebut masuk ke dalam ruangan sehingga dapat mengetahui sampai sejauh mana cahaya pantulan tersebut dapat masuk ke dalam ruangan.

\subsection{KRITERIA PENILAIAN GREEN MARK}

Green Mark mempunyai rating tool yang mana terdapat lima kriteria utama untuk penilaian suatu bangunan. Kelima kriteria utama tersebut adalah Energy Efficiency, Water Effeciency, Environmental Protection, Indoor Enveronmental Protection, dan Other Green Features. Kelima kriteria ini memiliki sub-kriterianya masing-masing. Setiap sub-kriteria memiliki maksimal poin dalam penilaian Green Mark ini.

Kriteria Energy Efficiency mempunyai jumlah maksimal poin paling banyak diantara kriteria lain. Dalam kriteria ini terdapat sub-kriteria yang berhubungan dengan pencahayaan alami siang hari. Sub-kriteria tersebut adalah NRB 1-5 Daylighting dan NRB 1-10 Energy Efficient Practices and Features.

\subsubsection{PASH / DAYLIGHTING}

Poin yang akan didapatkan dinilai dari seberapa jauh area dalam ruangan yang mendapatkan pencahayaan alami siang hari. 

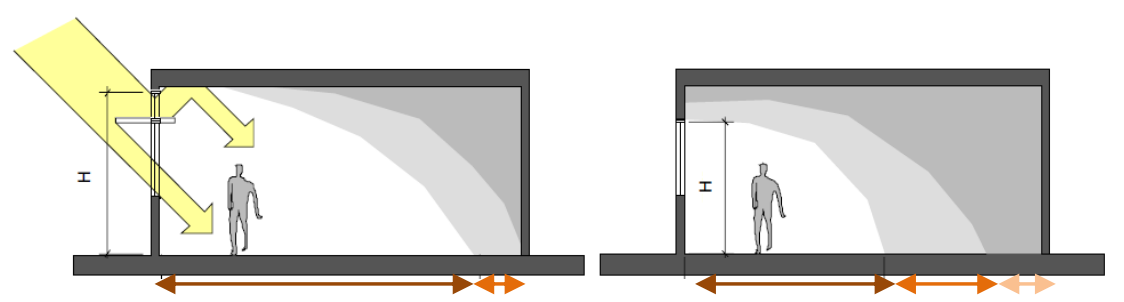

Figur 9. Ilustrasi kedalaman ruang yang mendapatkan PASH dengan menggunakan light shelf dan tanpa menggunakan light shelf.

(Sumber : Ernest Orlando; Tips for Daylighting)

Tabel 2.1. Alokasi poin untuk seberapa jauh PASH dapat masuk ke dalam ruangan.

\begin{tabular}{|c|c|}
\hline $\begin{array}{c}\text { Distance from the Facade } \\
\text { Perimeters (m) }\end{array}$ & Point Allocation \\
\hline$\geq 3.0$ & 1 \\
\hline $4.0-5.0$ & 2 \\
\hline$>5.0$ & 3 \\
\hline
\end{tabular}

(Sumber : BCAGreen Mark for New Non-Residential Building vers. 4.0, 2010, hlm. 10)

\subsubsection{ENERGY EFFICIENT PRACTICES \& FEATURES}

Dalam sub-kriteria ini dijelaskan bahwa pada poin fitur-fitur yang digunakan dalam bangunan yang dapat mengurangi penggunaan energi akan mendapatkan poin sampain dengan 3 poin untuk setiap $1 \%$ pengurangan total penggunaan energi pada bangunan. Dalam poin ini dijelaskan bahwa light shelf merupakan salah satu fitur yang dapat digunakan dalam bangunan.

\begin{tabular}{|l|c|}
\hline $\begin{array}{l}\text { (c) Use of energy efficient features. } \\
\text { Examples: }\end{array}$ & $\begin{array}{c}\text { 3 points for every } 1 \% \text { energy saving } \\
\text { over the total building energy consumption }\end{array}$ \\
- Heat recovery system & (Up to 10 points) \\
- Sun pipes & \\
- Lifts with gearless drive & \\
- Re-generative lift & \\
- - Photocell sensors to maximise the use of & \\
- daylighting & \\
\hline
\end{tabular}

Figur 10. Light shelf masuk ke dalam sub-kriteria efisiensi energi.

(Sumber : BCAGreen Mark for New Non-Residential Building VersionNRB/4.0, 2010, hlm. 11) 


\section{METODE PENELITIAN}

\subsection{OBJEK PENELITIAN}

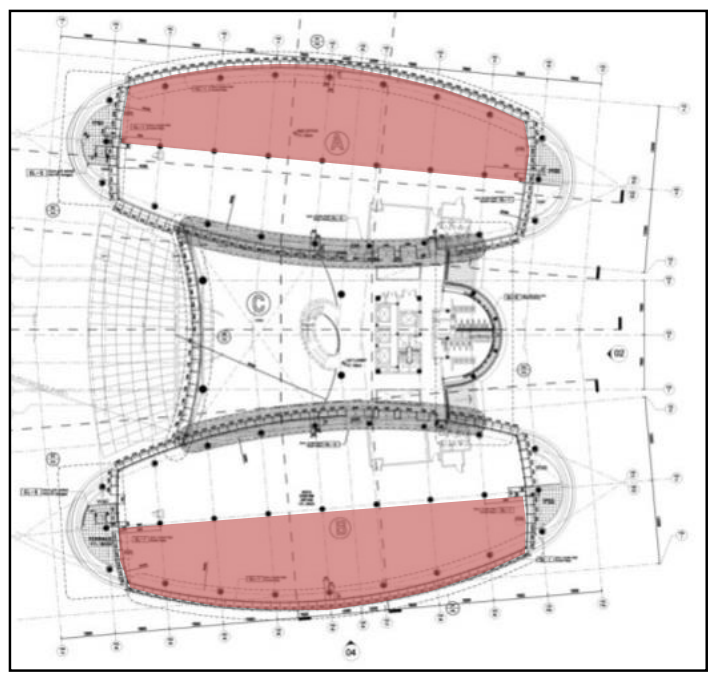

Figur 11. Area Amatan Pada Bangunan SML Plaza, Tangerang.

(Sumber : Sinar Mas Land)

Objek penelitian ini adalah bangunan kantor Sinar Mas Land Plaza yang dimiliki oleh Sinar Mas Land. Sinar Mas Land Plaza ini berada di BSD Green Office Park. Sinar Mas Land Plaza yang mempunyai desain khusus yaitu desain light shelf pada bangunannya. Pada Bangunan Sinar Mas Land Plaza, area amatan yang diamati merupakan area kantor lantai 1 baik pada Tower A (Utara) maupun Tower B (Selatan). Untuk simulasi, area yang digunakan sama dengan area amatan, yaitu area kantor lantai 1 yang menghadap langsung ke arah UtaraSelatan.

\subsection{JENIS PENELITIAN}

Penelitian ini menggunakan metode analisis data kuantitatif dimana akan dilakukan penelitian eksperimental melalui simulasi menggunakan software Autodesk Ecotect. Simulasi Ecotect akan digunakan untuk mensimulasikan 3D modeling dari bangunan Sinar Mas Land Plaza dimana area yang dijadikan model untuk simulasi adalah area kantor lantai 1. (1) Observasi sebagai metode penelitian yang mencakup pengamatan dan pencatatan di lapangan terhadap fenomena-fenomena yang terjadi. (2) Simulasi dari perhitungan yang dilakukan dari objek yang diteliti dan mendapatkan hasil perhitungan menurut simulasi melalui program Autodesk Ecotect.

\subsection{BATASAN PENELITIAN}

Penelitian ini merupakan bagian dari evaluasi desain light shelf pada bangunan kantor Sinar Mas Land Plaza Tangerang dan penelitian ini juga merupakan bagian dari upaya peningkatan pada desain light shelf pada bangunan Sinar Mas Land Plaza untuk penilaian Green mark. Karena keterbatasan waktu penelitian maka untuk penelitian kali ini ditentukan beberapa kondisi sebagai batasan penelitian. Beberapa kondisi tersebut adalah sebagai berikut: (1) Desain light shelf eksisting yang mencakup posisi, lebar, dan material tidak direkayasa. Posisi dari light shelf berada pada ketinggian 2,2 m terhitung dari permukaan lantai, sedangkan untuk lebar light shelf yang digunakan untuk simulasi sama dengan ukuran desain light shelf eksisting.Material yang digunakan untuk simulasi menggunakan material yang sama dengan material light shelf eksisting yaitu ACP. (2) Penelitian ini terfokus kepada penelitian desain 
eksterior light shelf, sehingga interior light shelf tidak direkayasa. (3) Bukaan pencahayaan pada bangunan tidak terbayangi oleh objek lain dengan kondisi langit cerah.

\subsection{TEMPAT DAN WAKTU PENELITIAN}

Penelitian ini menggunakan simulasi Ecotect yang mana lokasi yang menjadi data input untuk simulasi ini adalah kota Jakarta. Weather file yang akan diinput ke dalam simulasi Ecotect menggunakan weather file kota Jakarta yang mempunyai satu karakteristik yang sama dengan kota Tangerang. Untuk waktu penelitian yang diinput ke dalam simulasi Ecotect adalah 21 Juni, 21 September, 21 Oktober, dan 21 Desember pada pk. 08.00, 10.00, 12.00, dan 14.00.

\subsection{SUMBER DATA}

Data-data yang didapatkan untuk penelitian ini didapatkan dengan 2 cara yaitu: (1) Observasi sebagai metode penelitian yang mencakup pengamatan dan pencatatan di lapangan terhadap fenomena-fenomena yang terjadi. (2) Simulasi dari perhitungan yang dilakukan dari objek yang diteliti dan mendapatkan hasil perhitungan menurut program Autodesk Ecotect.

\subsection{TEKNIK PENGUMPULAN DATA}

Observasi sebagai metode penelitian yang mencakup pengamatan dan pencatatan di lapangan terhadap fenomena-fenomena yang terjadi. Dalam hal ini dilakukan pengamatan mengenai jenis-jenis material yang digunakan mulai dari material fasad, light shelf, plafon dan juga lantai.

Simulasi dari perhitungan yang dilakukan dari objek yang diteliti dan mendapatkan hasil perhitungan menurut program Autodesk Ecotect. Simulasi menggunakan software ini adalah untuk membandingkan hasil yang didapatkan di lapangan dengan hasil dari software tersebut.

\subsection{ALAT PENGUKUR DATA}

Pada penelitian ini digunakan software untuk simulasi yaitu software Autodesk Ecotect. Ecotect merupakan software yang digunakan untuk mengukur jumlah illuminan dalam ruang kantor dan juga untuk melihat masuknya cahaya alami siang hari ke dalam ruang kantor.

\subsection{LANGKAH PENELITIAN}

\subsubsection{TAHAP PENDAHULUAN}

Pada tahap pendahuluan dilakukan kajian teoritik untuk memberikan gambaran tentang peran light shelf dalam penilaian Green Mark BCA, serta memberikan gambaran tentang strategi pencahayaan alami siang hari yang mana salah satu strateginya adalah light shelf. Untuk dapat melihat kinerja light shelf yang optimal, maka dibutuhkan parameter desain untuk menilainya. Parameter tersebut dilihat dari aspek bentuk plafon, bentuk, ukuran, dan kemiringan light shelf.

\subsubsection{TAHAP PERANCANGAN MODEL UNTUK SIMULASI}

a. Model light shelf Eksisting

Model light shelf yang akan disimulasikan pertama adalah model light shelf eksisting untuk mengetahui kinerja light shelf eksisting. 

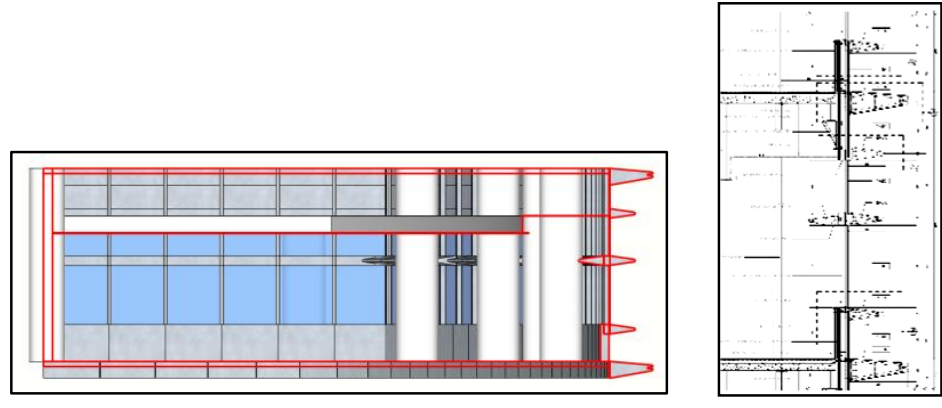

Figur 12. Model Desain Light shelf Eksisting.

\section{b. Model Modifikasi Bentuk Plafon}

Model kedua yang akan disimulasikan adalah model light shelf eksisting dengan modifikasi pada bentuk plafon untuk membangsingkan kinerja desain plafon eksisting dengan desain plafon rekayasa.

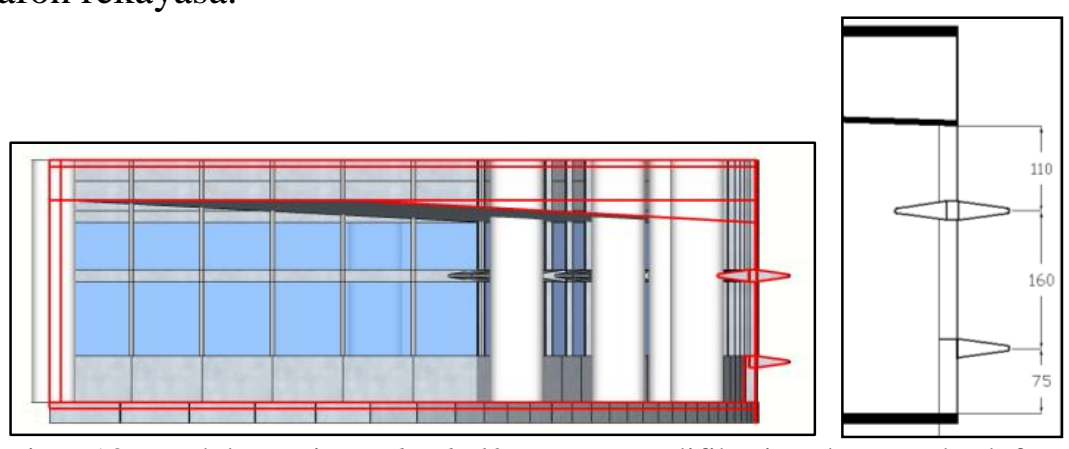

Figur 13. Model Desain Light shelf Dengan Modifikasi Pada Bentuk Plafon.

\section{c. Model Modifikasi Bentuk Light shelf}

Model ketiga dan keempat yang akan disimulasikan adalah model light shelf dengan modifikasi pada bentuk light shelf yaitu bentuk datar dan lengkung.

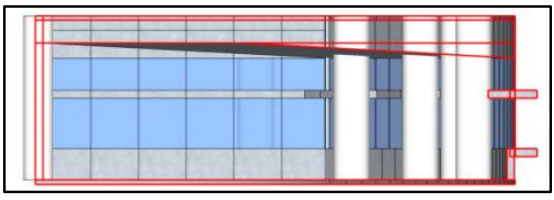

Figur 14. Model Desain Light shelf Dengan Modifikasi Pada Bentuk Light shelf Yaitu Bentuk Datar.

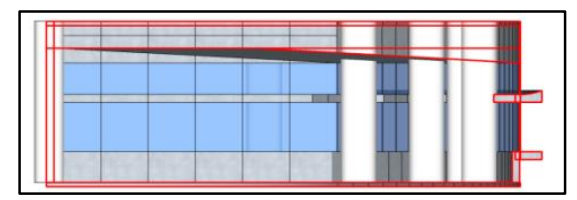

Figur 15. Model Desain Light shelf Dengan Modifikasi Pada Bentuk Light shelf Yaitu Bentuk Lengkung.

d. Model Modifikasi Kemiringan Light shelf

Model kelima dan keenam yang akan disimulasikan adalah model light shelf dengan modifikasi pada kemiringan light shelf yaitu dengan sudut $10^{\circ}, 20^{\circ}$, dan $30^{\circ}$. 
Figur 16. Model Desain Light shelf dengan Modifikasi Pada Kemiringan Light shelf dengan Sudut Kemiringan $10^{\circ}, 20^{\circ}, 30^{\circ}$.
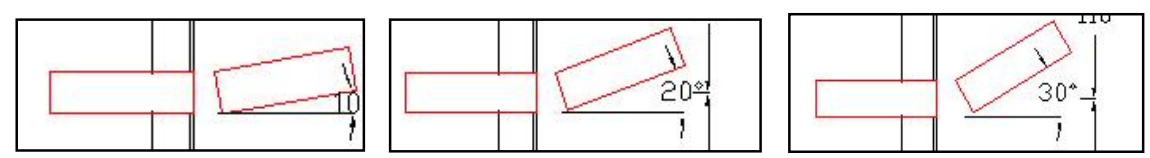

Figur 17. Model Desain Light shelf dengan Modifikasi Pada Kemiringan Light shelf dengan Sudut Kemiringan $10^{\circ}, 20^{\circ}, 30^{\circ}$.

\subsubsection{TAHAP SIMULASI}

Pada tahap ini dilakukan simulasi untuk semua model yang telah dibuat dengan menggunakan simulasi Ecotect.

\subsubsection{TAHAP DATA HASIL PENGUKURAN DAN ANALISIS}

Pada tahap ini akan dilakukan pengukuran terhadap jarak kedalaman penetrasi cahaya alami siang hari dari hasil simulasi yang telah dilakukan.

\subsubsection{Tahap Kesimpulan dan Saran}

Pada tahap ini akan dirangkum semua hasil dari simulasi yang telah dilakukan. Hasil kesimpulan berupa desain light shelf yang tepat digunakan pada masing-masing orientasi Utara dan Selatan, yang berguna untuk meningkatkan penilaian Green Mark BCA.

\subsection{TEKNIK ANALISIS DATA}

Analisis kuantitatif dengan hasil melalui observasi, pengukuran, dan simulasi, maka hasil tersebut akan diolah yang kemudian akan dibandingkan dengan standar yang berlaku.

\section{HASIL DAN PEMBAHASAN}

\subsection{ANALISA DESAIN LIGHT SHELF EKSISTING}

Berdasarkan hasil simulasi dari desain light shelf eksisting pada waktu yang telah ditentukan sesuai dengan batasan penelitian, dapat dilihat bahwa desain light shelf pada bangunan Sinar Mas Land Plaza yang sekarang tidak efektif pada waktu-waktu tertentu di semua orientasi baik orientasi Utara maupun orientasi Selatan. 


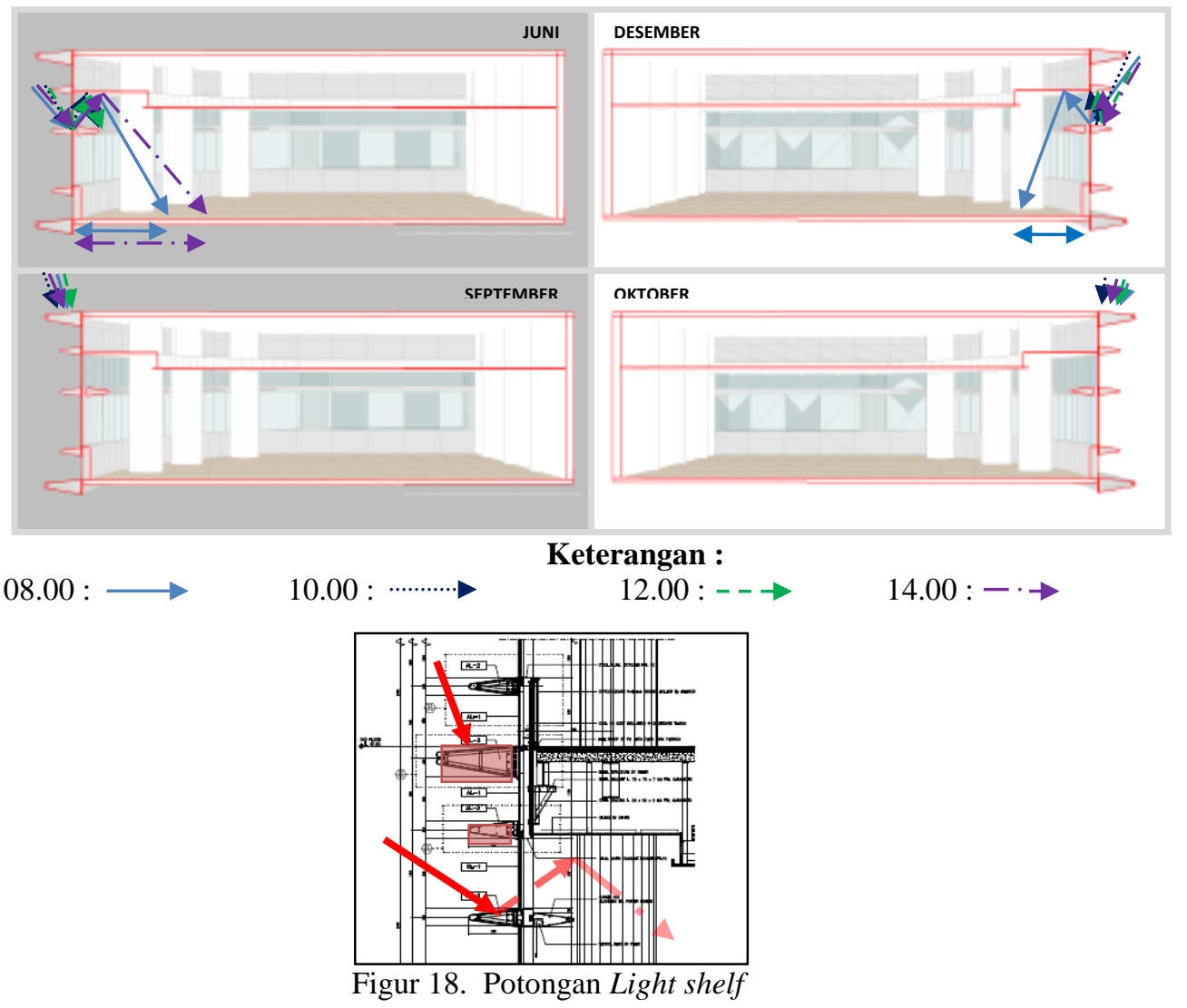

Jika dilihat dari desain light shelf pada bangunan Sinar Mas Land Plaza ada beberapa masalah yang terdapat pada desain light shelf pada bangunan ini. Yang pertama adalah desain dari sirip yang berada di atas light shelf yang mungkin menghalangi masuknya cahaya matahari langsung ke dalam ruangan.

\subsection{ANALISA DESAIN LIGHT SHELF DALAM ASPEK PLAFON}

Setelah dilakukan beberapa simulasi pada model bangunan, dari hasil simulasi tersebut terlihat bahwa dengan tidak adanya overhang yang berada di atas eksterior light shelf, cahaya matahari langsung tidak terhalangi sehingga fungsi dari light shelf lebih efektif.

Berdasarkan teori, desain plafon miring merupakan desain yang paling optimal dalam memantulkan cahaya matahari jauh lebih dalam ke dalam ruangan.

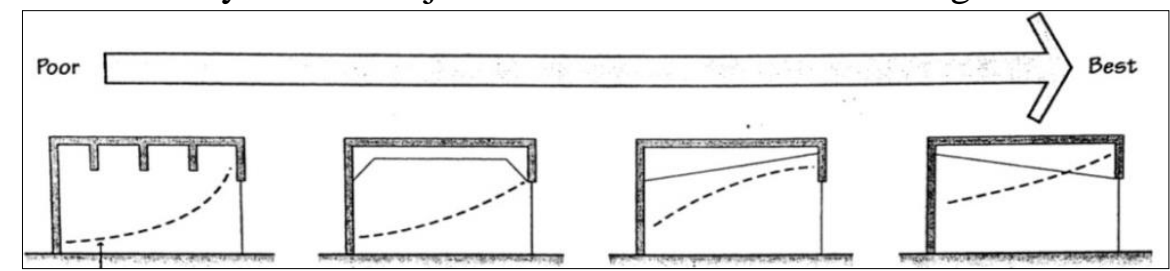

Figur 18. Perbandingan Gradian Illuminan Terhadap Bentuk Plafon.

(Sumber : Architectural Lighting Second Edition: M. David Egan, Victor Olgyay, 2002, hlm. 109)

Berdasarkan hasil simulasi diketahui bahwa dengan desain plafon miring, jarak penetrasi cahaya alami siang hari lebih jauh dibandingkan dengan dengan plafon eksisting. 


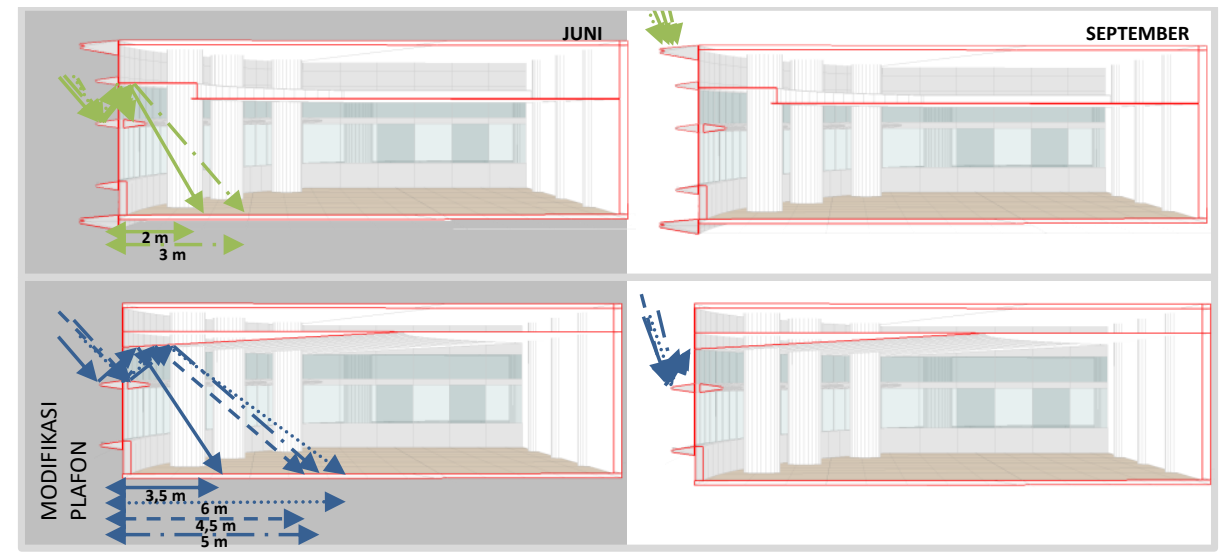

Figur 19. Perbandingan Jarak Penetrasi Cahaya Alami Siang Hari antara Desain Plafon Eksisting dengan Desain Plafon Miring pada Orientasi Utara.

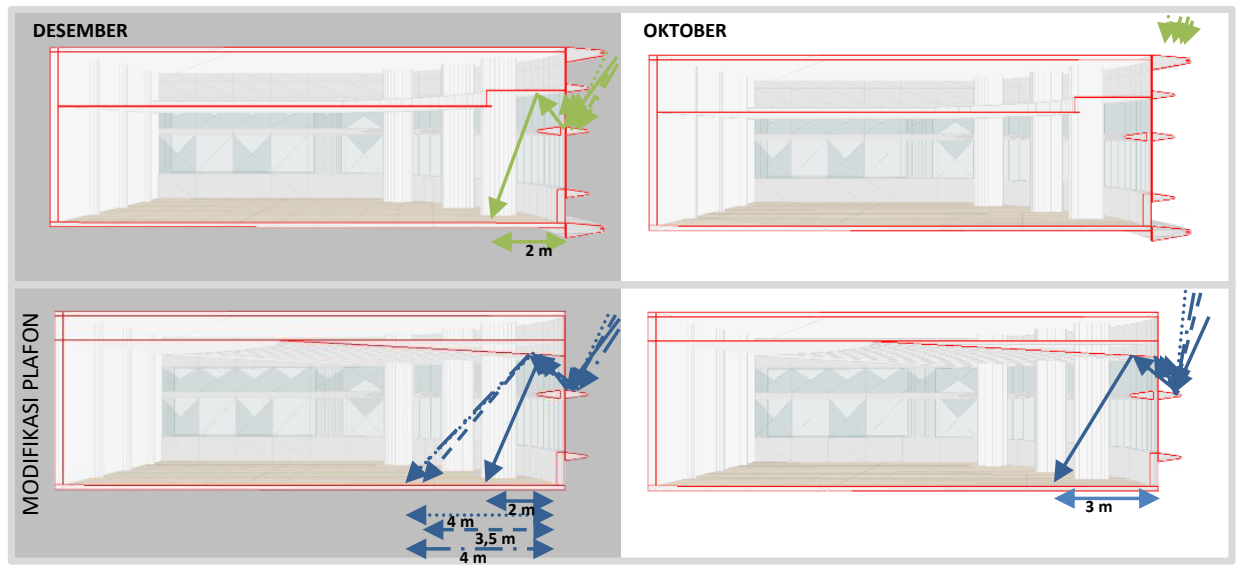

Figur 20. Perbandingan Jarak Penetrasi Cahaya Alami Siang Hari antara Desain Plafon Eksisting dengan Desain Plafon Miring pada Orientasi Selatan.

\subsection{ANALISA MODIFIKASI DESAIN LIGHT SHELF PADA ORIENTASI UTARA}

Berdasarkan hasil simulasi yang dilakukan terdapat kelebihan dan kekurangan dari setiap simulasi yang dilakukan yaitu:

1. Analisa Desain Light Shelf Dalam Aspek Desain Plafon

$\checkmark$ Penetrasi cahaya alami meningkat dibandingkan dengan eksisting

$\times$ Pada bulan tertentu seperti September, cahaya tidak ada yang masuk.

2. Analisa Desain Light Shelf Dengan Bentuk Datar

$\times$ Penetrasi cahaya pada bulan Juni mengalami penurunan pada waktu tertentu

3. Analisa Desain Light Shelf Dengan Bentuk Lengkung

$\checkmark$ Penetrasi cahaya alami meningkat baik pada bulan Juni maupun September

4. Analisa Desain Light Shelf Dengan Kemiringan $10^{0}$

$\times$ Penetrasi cahaya alami mengalami penurunan

5. Analisa Desain Light Shelf Dengan Kemiringan $20^{\circ}$

$\checkmark$ Penetrasi cahaya alami meningkat

$\times$ Pada bulan Juni pk. 08.00 cahaya matahari yang dipantulkan oleh light shelf langsung masuk ke dalam ruangan tanpa dipantulkan kembali oleh plafon.

6. Analisa Desain Light Shelf Dengan Kemiringan $30^{\circ}$

$\checkmark$ Penetrasi cahaya alami meningkat pada bulan September 
$\times$ Pada bulan Juni, cahaya yang masuk ke dalam ruangan merupakan cahaya pantulan langsung dari light shelf

Berikut adalah hasil analisa dari hasil simulasi desain light shelf pada orientasi Utara:

\section{1}

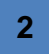

3

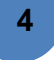

5

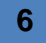

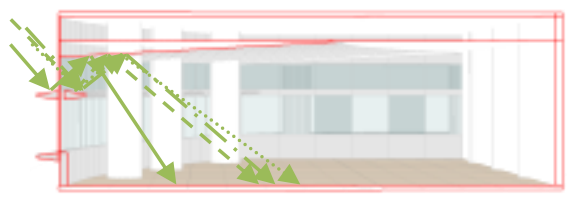
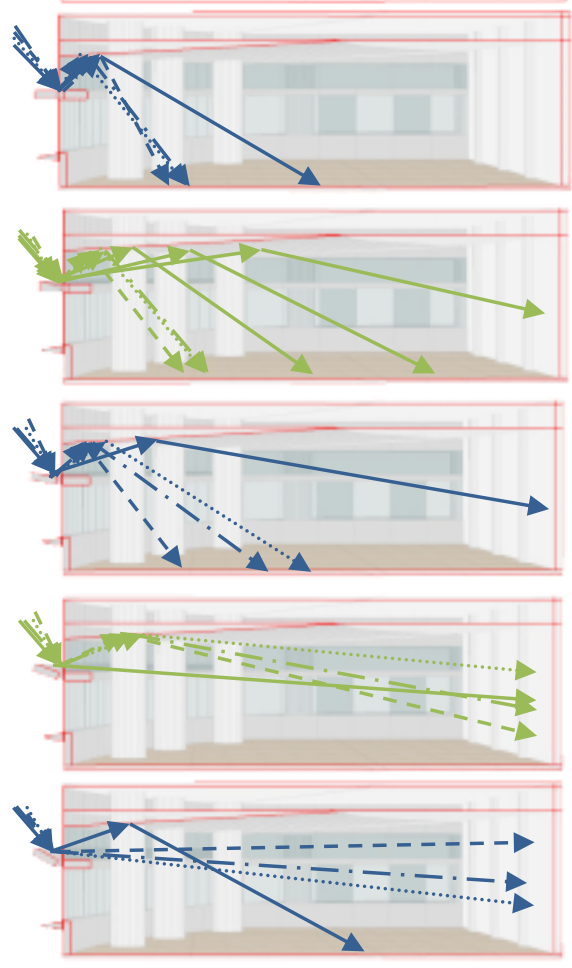

Figur 21. Hasil Simulasi Desain Light Shelf Pada Orientasi Utara.
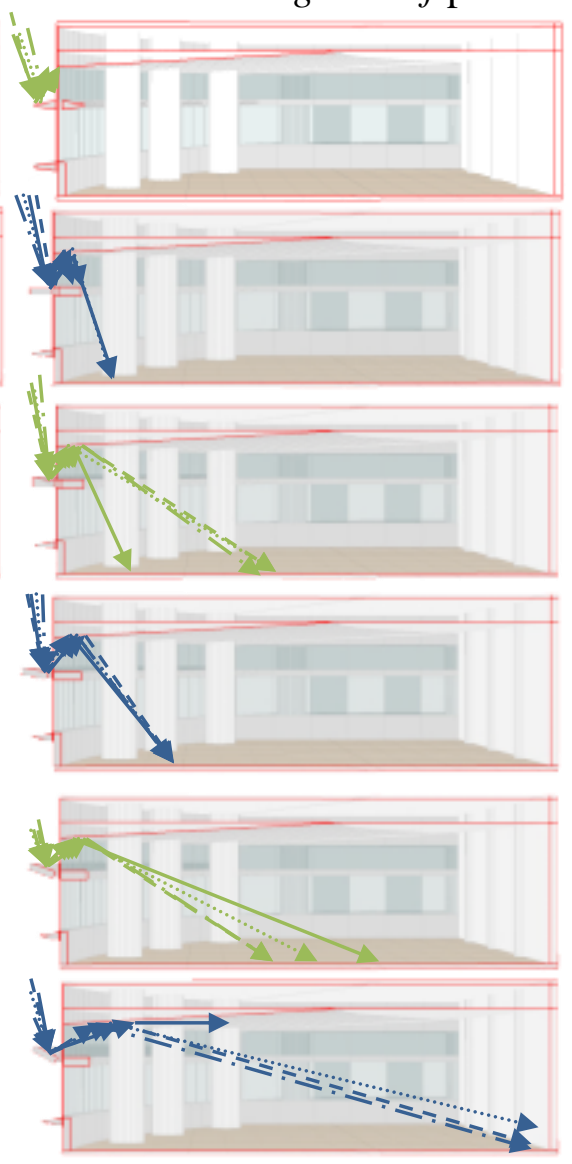

\section{(1)}




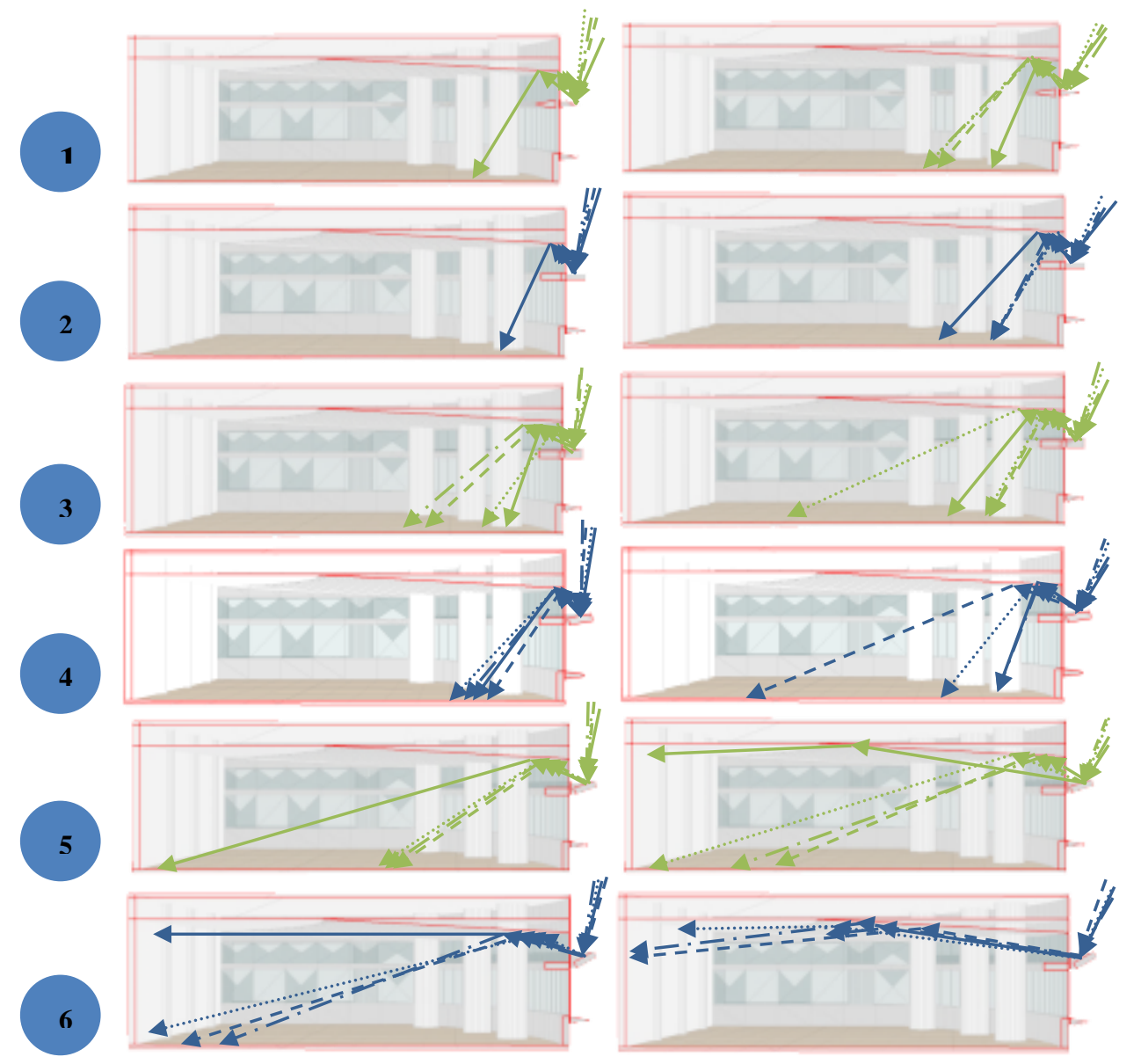

Figur 21. Hasil Simulasi Desain Light Shelf Pada Orientasi Utara.

Berdasarkan hasil simulasi yang dilakukan terdapat kelebihan dan kekurangan dari setiap simulasi yang dilakukan yaitu:

1. Analisa Desain Light ShelfDalam Aspek Desain Plafon

$\checkmark$ Penetrasi cahaya alami meningkat dibandingkan dengan eksisting

$\times$ Pada bulan tertentu seperti Oktober, cahaya yang masuk ke dalam ruang hanya pk. 08.00

2. Analisa Desain Light Shelf Dengan Bentuk Datar

$\times$ Tidak terjadi peningkatan dalam penetrasi cahaya pada bulan Desember maupun bulan Oktober

3. Analisa Desain Light Shelf Dengan Bentuk Lengkung

$\checkmark$ Penetrasi cahaya alami meningkat baik pada bulan Desember maupun Oktober

4. Analisa Desain Light Shelf Dengan Kemiringan $10^{\circ}$

$\checkmark$ Terjadi peningkatan penetrasi cahaya alami pada waktu-waktu tertentu

$\times$ Penetrasi cahaya alami mengalami penurunan pada bulan September.

5. Analisa Desain Light Shelf Dengan Kemiringan $20^{\circ}$

$\checkmark$ Penetrasi cahaya alami meningkat signifikan terutama pada bulan Oktober

$\checkmark$ Pada bulan Desember, cahaya yang dipantulkan dari plafon jatuh ke arah bidang kerja

6. Analisa Desain Light Shelf Dengan Kemiringan $30^{\circ}$

$\checkmark$ Penetrasi cahaya alami meningkat signifikan baik pada bulan Desember maupun Oktober

× Pada bulan Desember, cahaya yang dipantulkan dari plafon jatuh ke area sirkulasi bukan bidang kerja 


\section{KESIMPULAN DAN SARAN}

\subsection{KESIMPULAN}

\subsubsection{PERAN LIGHT SHELF EKSISTING TERHADAP PENILAIAN GREEN MARK}

Berdasarkan hasil penelitian yang dilakukan diketahui bahwa kinerja desain light shelf eksisting tidak optimal dikarenakan oleh sirip yang berada di atas light shelf yang menghalangi cahaya matahari langsung yang akan dipantulkan masuk ke dalam ruangan. Bentuk dan kemiringan dari light shelf serta desain plafon eksisting pun mempengaruhi cahaya alami siang hari yang masuk ke dalam ruangan. Sehingga diperlukan upaya perbaikan dari desain light shelf untuk meningkatkan penilaian Green Mark.

\subsubsection{UPAYA PERBAIKAN DESAIN LIGHT SHELF PADA BANGUNAN SINAR MAS LAND PLAZA TANGERANG}

Setelah dilakukan beberapa simulasi menggunakan beberapa model dari desain light shelf dapat disimpulkan bahwa: (1) Berdasarkan penelitian yang dilakukan, desain light shelf yang efektif untuk digunakan pada orientasi Utara adalah desain light shelf dengan bentuk lengkung. (2) Berdasarkan penelitian yang dilakukan, desain light shelf yang efektif untuk digunakan pada orientasi Selatan adalah desain light shelf dengan kemiringan $20^{\circ}$. (3) Dengan adanya upaya perbaikan desain light shelf pada bangunan Sinar Mas Land Plaza, maka terjadi peningkatan penilaian Green Mark sebanyak 3 poin untuk sub-kriteria NRB 1-5 Daylighting. (4) Berdasarkan hasil penilaian Green Mark, diketahui bahwa total konsumsi energi listrik untuk area kantor adalah sebesar 3,3\% dari keseluruhan konsumsi energi listrik bangunan. Jika upaya perbaikan dari desain light shelf dapat bekerja dengan optimal, maka diasumsikan konsumsi energi listrik dapat berkurang hingga 1,68\%. Dengan adanya pengurangan konsumsi energi listrik pada siang hari, maka bangunan dapat menghemat energi 1,68\%, sehingga bisa mendapatkan 5 poin untuk sub-kriteria NRB 1-10 Energy Efficient Practices \& Features. (5) Jika desain light shelf ini diterapkan pada bangunan Sinar Mas Land Plaza Tangerang maka penambahan poin yang akan didapatkan dalam penilaian Green Mark adalah 8 poin. Dengan penambahan 8 poin, srtifikasi Green Mark bangunan Sinar Mas Land Plaza Tangerang yang semula berada pada tingkat Gold dapat ditingkatkan ke tingkat Platinum.

\subsection{SARAN}

Setelah dilakukan beberapa simulasi dan mendapatkan kesimpulan untuk setiap rumusan masalah, maka terdapat beberapa saran yaitu: (1) Sirip yang berada di atas light shelf eksisting dapat dipertahankan hanya jika panjang dari sirip tersebut tidak menghalangi arah cahaya matahari langsung (diperpendek ukurannya). (2) Konsekuensi bentuk light shelf dan kemiringan light shelf akan memepengaruhi sistem stuktur dari light shelf dan aliran air hujan. (3) Perlu adanya pengembangan terhadap bentuk dari light shelf, karena pada penelitian ini bentuk yang digunakan merupakan bentuk geometri dasar. Pengembangan bentuk light shelf berpengaruh pada nilai estetika dari tampilan facade bangunan yang dilihat dari bentuk light shelf.

\section{DAFTAR PUSAKA}

Beltran, L. O., LEE, E. S. dan SELKOWITZ, S. E. (1996). Advanced Optical Daylighting Systems: Light Shelf and Light Pipes. Makalah tidak dipublikasikan dan disajikan pada 1996 IESNA Annual Conference, Cleveland, $\mathrm{OH}$.

Egan, M. David dan OLGYAY, Victor. (2002) . Architectural Lighting Second Edition. New York: McGraw-Hill.

Frick, Heinz., ARDIYANTO., ANTONIUS dan DARMAWAN, AMS. (2008). Ilmu Fisika Bangunan. Yogyakarta: Penerbit Kanisius. 
GW, Ode Rapija., Kusumo \& Beta Suryo. (2011). Studi Evaluasi Pencahayaan Alami pada Gedung Kuliah Bersama III Universitas Muhammadiyah Malang. Media Teknik Sipil, Vol. 9, No. 1, Februari 2011: 50 -60.

Lam, W. M. C. (1986). Sunlighting as Formgiver for Architecture. New York. Van Nostrand Reinhold.

Milaningrum, Tri Hesti. (2015). Optimalisasi Pencahayaan Alami dalam Efisiensi Energi di Perpustakaan UGM. Makalah tidak dipublikasikan dan disajikan pada Sminar Topik Khusus, UGM, Yogyakarta.

Phillips, D., (2004). Daylighting: Natural Light in Architecture. Oxford: Architectural Press.

Rosenfeld, A.H. \& S. E. Selkowitz (1977). Beam Daylighting, Energy and Buildings. Beijing: Elsevier. Satwiko, Prasasto. (2004). Fisika Bangunan 1. Yogyakarta: CV. Andi Offset.

Smith, P., (2005), Architecture in A Climate of Change, 2nd Ed. Oxford: Architectural Press.

Indonesia. Standar Nasional Indonesia SNI 03-6197-2000. (2000). Konservasi Energi Sistem Pencahayaan pada Bangunan Gedung. Jakarta: Badan Standarisasi Nasional.

Thojib, Jusuf \& Muhammad Satya Adhitama. (2013). Kenyamanan visual melalui pencahayaan alami pada kantor. Jurnal RUAS, Vol. 11, No. 2.

Tiono, Evan Prabowo \& Indriani, Hedy C. (2015). Pengaruh eksperimen light shelf terhadap pencahayaan alami pada ruang kerja. Jurnal INTRA, Vol. 3, No. 2.

Zakhour, Suhail. (2015). The Influence of Selected Design Parameters on the Performance of Light Shelves under Overcast Condition. Architecture Research 2015, Vol. 5, No. 4, pp. 113-120. 